\title{
Intrusive Seismic Swarms as Possible Precursors of Destructive Earthquakes on Mt. Etna's Eastern Flank
}

\author{
Salvatore Gambino ${ }^{1}{ }^{1}$ and Giovanni Distefano ${ }^{2}{ }^{2}$ \\ ${ }^{1}$ Istituto Nazionale di Geofisica e Vulcanologia, Sezione di Catania, Piazza Roma 2, 95123 Catania, Italy \\ ${ }^{2}$ Dipartimento di Scienze Biologiche, Geologiche e Ambientali, Università degli Studi di Catania, Catania, Italy \\ Correspondence should be addressed to Salvatore Gambino; gambino@ct.ingv.it
}

Received 23 November 2021; Accepted 27 January 2022; Published 7 February 2022

Academic Editor: Filippos Vallianatos

\begin{abstract}
Copyright (c) 2022 Salvatore Gambino and Giovanni Distefano. This is an open access article distributed under the Creative Commons Attribution License, which permits unrestricted use, distribution, and reproduction in any medium, provided the original work is properly cited.
\end{abstract}

\begin{abstract}
The Timpe Fault System (TFS) represents the source of shallow earthquakes that strike numerous towns and villages on Mt. Etna's eastern flank. In the last 40 years, three destructive seismic events reached $I_{0}=$ VIII EMS (heavily damaging) in 1984 (October 25), 2002 (October 29), and 2018 (December 26). These events followed a few days after the occurrence of strong seismic swarms and the sudden acceleration of the eastern flank seaward. The damaging seismic events in 2002 and 2018 were associated with dike intrusions and eruptions of the volcano; however, no eruptive activity was observed at the time of the 1984 earthquakes. In this study, we investigate seismic parameters for the 1984 sequence, in order to interpret the seismicity in terms of volcanic activity. Parameters such as localization, cumulative seismic moment, and hourly occurrence frequency of the 1984 seismic swarm have been analysed and shown to have typical values of Mt. Etna's intrusive seismic swarms. This suggests that the 1984 episode may have been an aborted intrusive magma episode that triggered similar processes (long and powerful intrusions with acceleration of the eastern flank movement and destructive earthquakes), as in 2002 and 2018. These three episodes suggest that an evaluation of some seismic parameters during future intrusive swarms may furnish indications of a possible reactivation of the TFS.
\end{abstract}

\section{Introduction}

Mt. Etna is a stratovolcano of about 3300 meters high, built up over the past $500 \mathrm{ka}$ on the eastern coast of Sicily, and is one of the most active volcanoes on Earth (Figure 1). At the intersection of two regional structural trends, NE-SW and NNW-SSE oriented (inset in Figure 1), Mt. Etna is the result of a complex interaction between regional tectonics, flank instability processes, and basement geometry (e.g., $[1,2])$.

Volcanic activity on Mt. Etna comprises a persistent activity with episodic paroxysmal events, which occur close to the summit area, and hazardous flank eruptions that are generally preceded by intense intrusive seismic swarms and ground deformation (e.g., [3]).

Its southeastern flank, with an overall area of about $700 \mathrm{~km}^{2}$, moves ESE seaward continuously, at a rate of a few centimetres per year (e.g., $[4,5])$. This instability is mainly linked to eruptive activity (intrusion and magma pressuriza- tion), regional stress, and gravitational forces (e.g., [5-7]). The unstable flank is bordered to the north by the Pernicana fault system (PFS) and comprises many active tectonic structures located in the eastern and south-eastern flanks of the volcano, such as the Timpe Fault System (TFS) and the Trecastagni and Tremestieri faults [8], which dissect the eastern flank in different blocks characterized by inhomogeneous kinematics (e.g., [7, 9]).

PFS is characterized by fast ruptures, generating earthquakes with magnitude up to 4.2 that are closely correlated with acceleration phases of the unstable flank velocity [10, 11]. TFS is made up of several fault segments including the Fiandaca (FF), S. Tecla (STF), Moscarello (MOF), Leonardello (SLF), and S. Venerina (SVF) faults (Figures 1 and 2) characterized by normal and right-lateral kinematics [12-14]. These structures normally show right-lateral kinematics and normal dip slip with slip rates $(3.0$ to $5.0 \mathrm{~mm} / \mathrm{y})$. However, stress changes due to dike intrusion and accelerations of the 


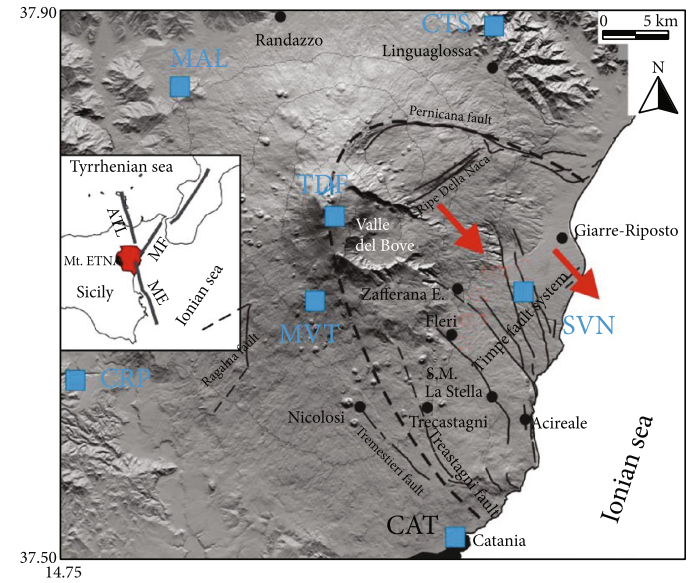

FIgURE 1: Surface fault map of Mt. Etna. Top inset map shows the main regional fault systems: $\mathrm{MF}=$ Messina-Fiumefreddo, $\mathrm{ME}=$ Malta Escarpment, and ATL = Aeolian-Tindari-Letojanni. Dashed line defines the sliding sector, and red arrows indicate its movement direction $. \mathrm{FF}=$ Fiandaca fault, $\mathrm{STF}=$ Santa Tecla fault, $\mathrm{SVF}=$ Santa Venerina fault, $\mathrm{MOF}=$ Moscarello fault, and $\mathrm{SLF}=$ San Leonardello fault. Blue squares show seismic stations of the University of Catania network operating on Etna in 1984.

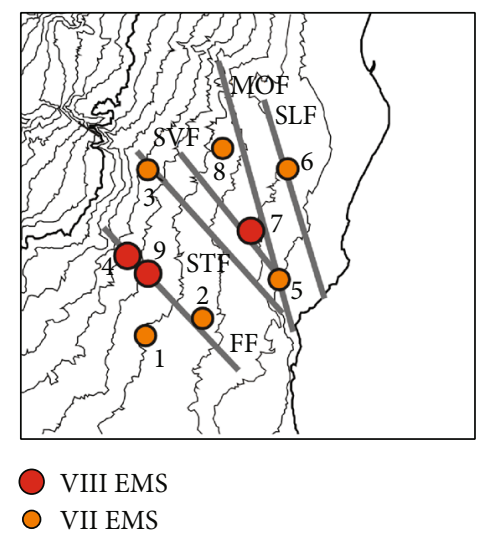

FIGURE 2: Macroseismic location of earthquakes with epicentral intensities $I_{0} \geq$ VIIEMS occurring from 1980 to 2019 in the southeastern flank of Mt. Etna [62]. Numbers are referred to in Table 1.

southern-eastern flank velocity may cause fast ruptures with displacements up to some tens of centimetres with strong seismic releases $[4,15,16]$.

Earthquakes taking place in Etna have magnitudes up to $\mathrm{Ml}=4.8$ (Colina et al. 2019; [13]) and are very shallow, reaching epicentral macroseismic intensity $\left(I_{0}\right)$ up to VIII (heavily damaging) on the EMS (European macroseismic scale) [17], with destructive effects in small areas. In the last 40 years (Table 1 and Figure 2), only three earthquakes on TFS have reached $I_{0}=$ VIII, namely, in 1984 (25 October at 01:11 UTC), 2002 (29 October at 10:02 UTC), and 2018 (26 December, 02:19 UTC). These episodes involved the FF (1984 and 2018) and the SVF (2002) structures ([18-20], Figure 2).

The 2002 and 2018 events were preceded by significant stress changes due to eruptive dike intrusion that triggered the vigorous eastward movement of the SE flank of Etna with activation of the PFS [16, 21-24].

The 2002 October 29 earthquake, with a magnitude of $\mathrm{Ml}=4.5$, caused heavy damage even to reinforced concrete structures in the epicentral area, along a narrow but elongated zone (over $4 \mathrm{~km}$ in length) where the macroseismic intensity reached degree VIII $[18,25]$.

The 2018 December 26 earthquake $(\mathrm{Ml}=4.8)$ nucleated on the Fiandaca fault, characterized by ruptures with perceivable opening and with a right-oblique average slip of $9 \mathrm{~cm}$ and a peak value of $35 \mathrm{~cm}$ [19]. Heavy damage due to ground shaking and surface displacement affected buildings, roads, and other man-made structures along the fault trace, leaving a thousand people homeless. Surface faulting extended for $\sim 8 \mathrm{~km} \mathrm{[26].}$

For the 2002 and 2018 cases, the relationship between the first cause (intrusion), the cascading effects (flank sliding acceleration and PFS activation), and TFS destructive earthquakes has been recognized by using Coulomb stress change patterns (e.g., [16, 24]).

What happened in 1984 is more difficult to understand for the limited data available. From October $16^{\text {th }}$, an anomalous large number of seismic events, concentrated mostly on the eastern side of the volcano, were recorded for several days on Mt. Etna [27], but no eruption occurred. The main destructive events occurred on October 19 and 25, 1984, with epicentral macroseismic intensity $I_{0}$ VII (damaging) and VIII (heavily damaging) EMS, respectively, striking the Zafferana territory and especially the villages of Fleri and Pisano [28]. The October $19^{\text {th }}$ event was located in proximity to the Santa Tecla fault (STF) and showed only small shifts $[28,29]$. Indeed, the October $25^{\text {th }}$ earthquake is linked to the Fiandaca fault (FF) that was affected by ground ruptures of the fault of about $20 \mathrm{~cm}[12,28]$. At that time, no GPS or InSAR measurements were in place; therefore, it has not been possible to verify an acceleration of the flank; however, through EDM (electronic distance measurement) data, Alparone et al. [11] showed that a flank sliding acceleration was active from October 1984 until 1986 to 1987.

In this paper, we suggest that the 1984 episode may have been an aborted intrusion that caused processes similar to those occurring in 2002 and 2018, thus better understanding the link between local seismicity and volcano dynamics. To investigate this possibility, we analyse the 1984 seismicity and examine if it presents features of intrusive seismic swarms which are typical for Mt. Etna.

\section{Seismic Data and Earthquake Location}

2.1. Seismic Data. During the second half of October 1984, an anomalous large number of seismic events, concentrated mostly on the eastern side of the volcano, were recorded on Mt. Etna [27]. The main events occurred on October $19^{\text {th }}$ and $25^{\text {th }}$, with epicentral macroseismic intensity $I_{0}=$ VII and $I_{0}=$ VIII (EMS), respectively. The first event struck Zafferana Etnea, while the second affected more seriously Fleri and Pisano villages and the NW-SE trending cracks along the FF with dip-slip displacements of more than $20 \mathrm{~cm}[12,28]$. 
TABLE 1: List of earthquakes recorded between 1980 and 2019 occurring on Mt. Etna's eastern flank with EMS $\geq 7$. EMS $=$ European macroseismic scale; $M_{\mathrm{m}}=$ macroseismic magnitude; $M_{\mathrm{L}}=$ local magnitude [62]. Bold lines represent the destructive events.

\begin{tabular}{ccccccccc}
\hline & Date & Time (UTC) & Epicentral area & Longitude & Latitude & EMS & $M_{\mathrm{m}}$ & $M_{\mathrm{L}}$ \\
\hline 1 & $20 / 07 / 1983$ & $22: 03$ & Viagrande & 37.613 & 15.101 & 7 & 4.0 & 4.3 \\
2 & $19 / 06 / 1984$ & $15: 19$ & Fiandaca & 37.636 & 15.131 & 7 & 3.8 & 4.0 \\
3 & $19 / 10 / 1984$ & $17: 43$ & Zafferana E. & 37.698 & 15.105 & 7 & 3.8 & 4.6 \\
4 & $\mathbf{2 5 / 1 0 / 1 9 8 4}$ & $\mathbf{0 1 : 1 1}$ & Fleri & $\mathbf{3 7 . 6 6 0}$ & $\mathbf{1 5 . 0 9 5}$ & $\mathbf{8}$ & $\mathbf{4 . 3}$ & $\mathbf{4 . 4}$ \\
5 & $02 / 02 / 1986$ & $16: 10$ & S. G. Bosco & 37.653 & 15.163 & 7 & 3.8 & 4.1 \\
6 & $29 / 01 / 1989$ & $07: 30$ & Codavolpe & 37.705 & 15.165 & 7 & 3.8 & 3.4 \\
7 & $\mathbf{2 9 / 1 0 / 2 0 0 2}$ & $\mathbf{1 0 : 0 2}$ & Bongiardo & $\mathbf{3 7 . 6 7 4}$ & $\mathbf{1 5 . 1 4 3}$ & $\mathbf{8}$ & $\mathbf{4 . 3}$ & $\mathbf{4 . 5}$ \\
8 & $29 / 10 / 2002$ & $17: 14$ & Milo & 37.717 & 15.118 & 7 & 4.0 & 3.9 \\
9 & $\mathbf{2 6 / 1 2 / 2 0 1 8}$ & $\mathbf{0 2 : 1 9}$ & Fleri & $\mathbf{3 7 . 6 4 8}$ & $\mathbf{1 5 . 1 1 7}$ & $\mathbf{8}$ & $\mathbf{4 . 3}$ & $\mathbf{4 . 8}$ \\
\hline
\end{tabular}

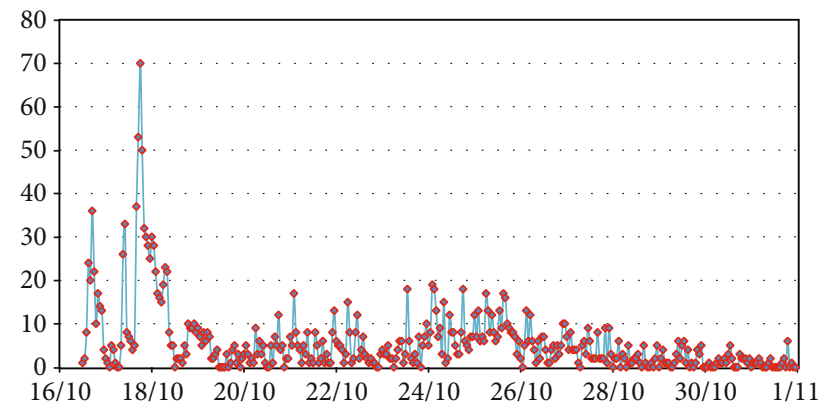

FIGURE 3: Earthquake hourly frequency at the CTS station from October 16 to October 31, 1984.

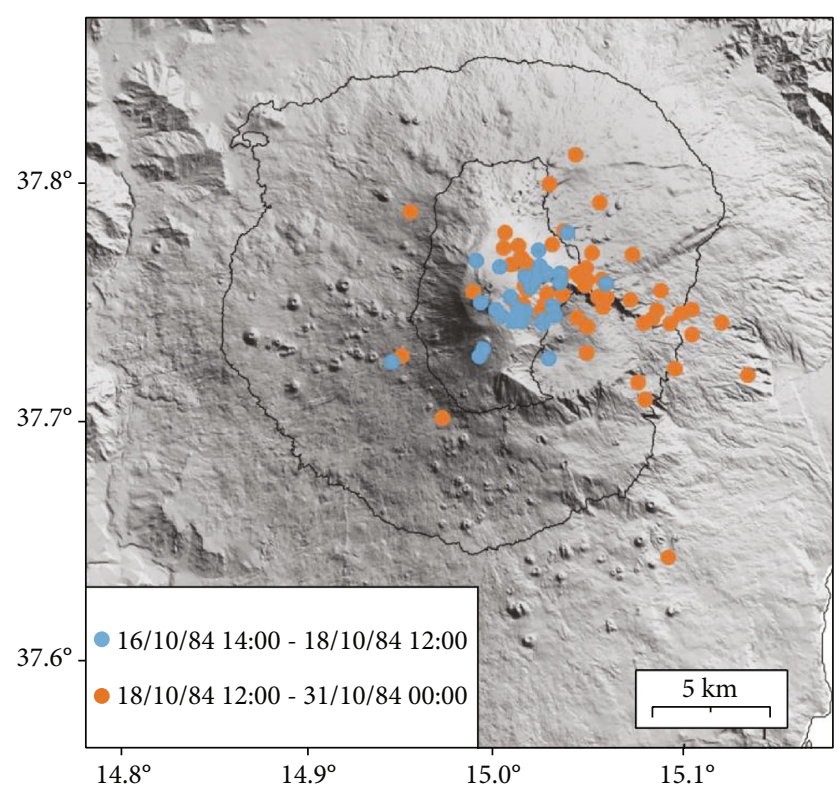

FIGURE 4: Epicentral location of selected earthquakes for the first (blue) and second (orange) phases.

The seismic swarm was recorded by using the permanent seismic network managed by the Catania University. Instrumental investigations of seismicity began at Mt. Etna at the end of the 1960s with a network that ran for about 30 years and included up to 11 one-component (vertical) stations equipped with $1.0 \mathrm{~Hz}$ seismometers [30, 31]. All times reported hereinafter are in GMT. Earthquake magnitudes are in the local magnitude scale unless otherwise indicated.

The swarms started on October $16^{\text {th }}$ at about 14:00 GMT, and ca. 2143 events were recorded until the $31^{\text {st }}$. The October 1984 swarm is one of the most powerful swarms known on Mt Etna, recording more than 50 events with $M \geq 3.0$ in 15 days. Figure 3 reports the hourly occurrence of earthquakes at the CTS station (Figure 1) that evidences two distinct phases of this seismicity. The first, from the $16^{\text {th }}$ at $14: 00$ to the $18^{\text {th }}$ at $12: 00$, had a high rate of activity (18.3 events/hour). The successive phase was characterized by an average rate of $\sim 5$ events/hour which increase slightly only close to the $25^{\text {th }}$. This change occurred after the $M=4.2$ earthquake located on the Pernicana fault on the $18^{\text {th }}$ at $11: 58$.

2.2. Earthquake Location. Of these events, about 600 earthquakes with $M>1.8$ were located by using HYPOELLIPSE [32] and the velocity model of Hirn et al. [33]. These locations show a scattered distribution because they were obtained through manual $\mathrm{P}$ and $\mathrm{S}$ waves picking on paper seismograms. Therefore, in order to have a more reliable picture of the seismic source locations, the dataset has been considerably reduced by taking into account only seismic events with more than 7 pickings, RMS $<0.5$, GAP $<180$, $\mathrm{ERH}<2.5 \mathrm{~km}$, and $\mathrm{ERZ}<3.0 \mathrm{~km}$. Following this procedure, we obtained 30 located events for the first phase and 55 for the second phase (Figure 4). The events belonging to the first group are mainly located a few kilometres to the east with respect to the summit craters, while the events after the $18^{\text {th }}$ at 12:00 are more distributed on the eastern flank of the volcano (Figure 4).

\section{The Intrusive Episodes at Mt. Etna}

3.1. Features of Intrusive Episodes. On Mt. Etna, the 19911993, 2001, 2002, 2008-2009, and 2018 eruptive episodes represent the main lateral eruptions occurring over the last 30 years. For each episode, a dike intrusion accompanied by an intense seismic swarm preceded the opening of eruptive fractures. Indeed, the dike propagation changes the stress field around the intrusion, causing a relevant number 


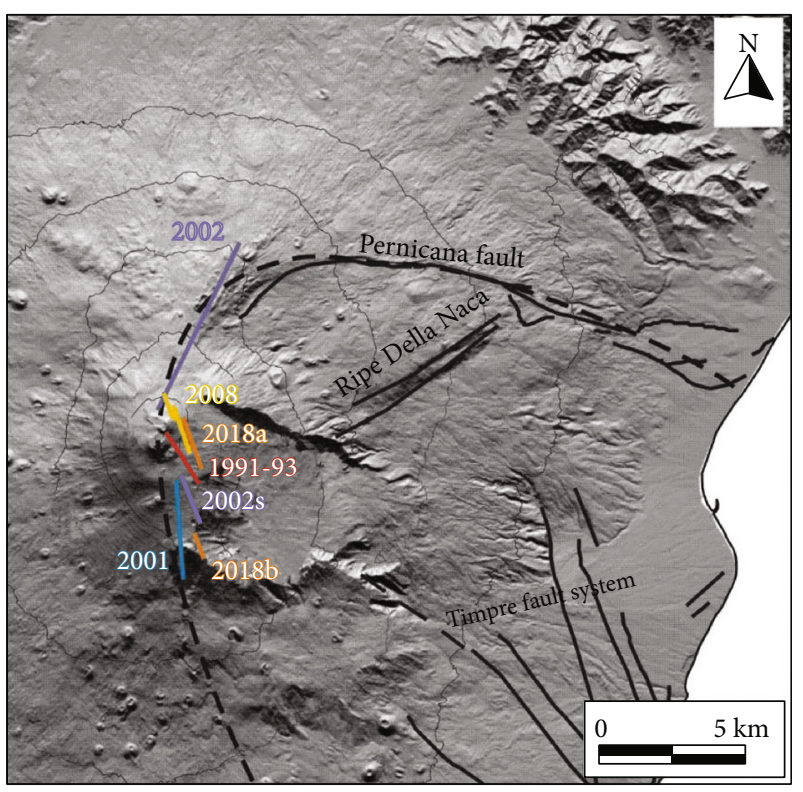

FIGURE 5: Map showing the eruptive dike intrusive sources obtained by modelling tilt and GPS ground deformation data [37, $39,44,47,50]$.

of earthquakes that occur close to the dike and activating structures and discontinuities in the nearby areas. This propagation is evidenced by changes in ground deformation measurements, whose modelling allows locating and characterizing the intrusive source (Figure 5). On Etna, the ability to obtain reliable models began in 1990 with the expansion and improvement of the continuous tilt and GPS permanent networks [34-36]. The above eruption episodes from 19911993 to 2018 have been extensively studied in dozens of papers.

The 1991-1993 eruption was characterized by low explosive activity and produced a very large lava field (total volume of magma of about $235 * 10^{6} \mathrm{~m}^{3}$ ). A shallow intrusion on the upper eastern flank, inferred by Bonaccorso et al. [37], was accompanied by a seismic swarm of 250 recorded events [38] occurring in the same area within 17 hours before the fractures opened on December 14, 1991 [30].

The eccentric eruption of 2001 was caused by the forceful uprising of a vertical dike (Bonaccorso et al. 2002; [39]) below the south flank (Figure 5), with magma ascending from a reservoir within the sedimentary substratum [40]. It was preceded by a seismic swarm occurring from July $12^{\text {th }}$ with 2645 events (with $M>1.0$ ) that affected the southern sector of the volcano in a main cluster, related to the dike intrusion, with a minor cluster on the upper S-SE sector of the volcano [39, 41, 42].

In particular, earthquakes of the main cluster from the $13^{\text {th }}$ to $14^{\text {th }}$ of July occurred at a depth between 2.5 and $1.2 \mathrm{~km}$ b.s.l., while from the $15^{\text {th }}$ of July (at 10:00 GMT), seismicity turned very shallow (confined at $\sim 0.5 \mathrm{~km}$ a.s.l.), shifting just below the eruptive fractures [39].

The 2002-2003 eruption was characterized by the first dike that ascended vertically in the southern flank close to the 2001 eruption site (2002 in Figure 5) and the second hor- izontal dike propagating radially in the NE flank, along the NE rift (2002 in Figure 5). Seismicity started at 20:12 on October $26^{\text {th }}, 2002$. During the first $3-4 \mathrm{~h}$, it took place in the southern-upper part of the volcano when a dikeforming intrusion ascended vertically through the edifice close to the 2001 eruption site $[43,44]$. Successively, the epicentral seismic pattern showed a northeastward migration of earthquakes along the NE rift with a second dike-forming intrusion that propagated laterally along the NE rift [44]. On the $27^{\text {th }}$ of October, at 01.28 , an earthquake of duration magnitude $M_{\mathrm{d}}=3.5$ involved the western tip of the Pernicana fault destroying the Piano Provenzana skiing station [45], while the eastern flank was successively characterized by an exceptional increase in the seaward movement [21].

The 2008 and 2018 eruptions were characterized by dike intrusions and the opening of lateral eruptive fissures located on the upper eastern flank (Figure 5).

On May $13^{\text {th }}, 2008$, at 08:40, a seismic swarm preceded and accompanied the beginning of the 2008-2009 eruption, when more than 240 seismic events were recorded in about 6-7 h, most of them occurring in the first two hours [46]. The largest earthquake $(M=3.9)$ occurred on May $13^{\text {th }}$, 2008, at 10:07. The eruption started with a fracture system between $3055 \mathrm{~m}$ and $2620 \mathrm{~m}$ a.s.l. [47], propagating from the summit craters toward the western wall of the Valle del Bove (e.g., Bonaccorso et al. 2011).

The earthquakes were located in the northeastern summit area at depths ranging between $1.5 \mathrm{~km}$ b.s.l. and $1.5 \mathrm{~km}$ a.s.l. [46]. In less than two hours, there was a clear migration of the seismic events toward the north [48], suggesting a propagation of a shallow intrusion toward this sector of the volcano [47]. The intrusion was very fast and marked by ground deformation recorded at permanent tilt and GPS stations [47].

In 2018, the eruptive fissures opened at the base of summit craters, with a small lateral eruption though the seismic swarm and ground deformation, were very strong. The initial seismicity (December $24^{\text {th }}$ at $8: 30$ ) was located beneath the summit craters and along the eruptive fracture with epicentres aligned in a N-S direction, between $-1 \mathrm{~km}$ a.s.l. and $1 \mathrm{~km}$ b.s.l. [49] involving the PFS with an event of $M=3.5$ at 10:27. From 8:30 to 11:10, Aloisi et al. [50] inferred one propagating magmatic intrusion (2018a in Figure 5) that ascended near vertically from the sea level toward the ground surface where eruptive fissures opened.

However, the continuous ground deformation a few hours after revealed a new elongated intrusion in the southern flank, matching the southward migration of seismicity with a deepening of the hypocentres up to $3 \mathrm{~km}$ b.s.l. [49] that did not reach the ground surface (2018b in Figure 5).

After the 24 December 2018 intrusion, the eastern flank was characterized by increased seaward velocity, clearly shown in the slope of the GNSS time series [51].

3.2. Intrusive Seismic Swarm Parameters. Seismic swarms accompanying the intrusive episodes described above consisted of hundreds of events that took place during the dike propagation and were testified by contemporary ground deformation changes; Table 2 lists parameters for each one 
TABLE 2: Intrusive seismic swarm parameters. The duration represents the time interval in which there is contemporaneity between seismicity and ground deformation ([30] and references therein; [50,63]). The seismic moment $M_{\mathrm{o}}$ was obtained by using (1) and (2) relationships. The 2018 values comprise an estimate of $2.0 * 10^{15} \mathrm{Nm}$ for the 1425 events with $M<1.4$ not included in the Bonaccorso and Giampiccolo [52] calculus. The last row reports data of the first phase of the October 1984 seismic swarm (16th at 14:00-18th at 12:00).

\begin{tabular}{lccccc}
\hline Eruptive episode & Type & Duration (hours) & Seismic events $\left(n^{\circ}\right)$ & Seismic events (events/hour) & $M_{\mathrm{o}}(\mathrm{Nm})$ \\
\hline $1991-93$ & Lateral & 17.0 & 250 & 14.70 & $4.09 E+15$ \\
2001 & Eccentric & 113.0 & 2694 & 23.84 & $4.35 E+16$ \\
2002 & Lateral & 19.5 & 294 & 15.08 & $1.89 E+16$ \\
2008 & Lateral & 6.4 & 230 & 35.94 & $6.80 E+15$ \\
2018 & Lateral & 31.5 & 1560 & 49.52 & $1.36 E+16$ \\
1984 & No eruption & 43.0 & 813 & 18.91 & $1.55 E+16$ \\
\hline
\end{tabular}

of the seismic swarms such as duration, number of events recorded, earthquake activity rate, and cumulative seismic moment.

On Mt. Etna, the duration of an intrusive process is highly variable, ranging from a few to 113 hours, while the number of earthquakes ranges between a couple of hundred events to a couple of thousand events with an activity rate between 15 and 50 events/hour. The seismic moment varies within an order of magnitude between ca. $4.0 * 10^{15} \mathrm{Nm}$ and $4.0 * 10^{16} \mathrm{Nm}[30,52]$.

The last row of Table 2 shows the same parameters obtained for the first phase of the October 1984 seismic swarm (813 events in 43 hours, an hour frequency of ca. 19 events per hour, and an estimated cumulative seismic moment of $1.55 * 10^{16} \mathrm{Nm}$ ).

The seismic moment has been obtained from the Giampiccolo et al. (2007) equation:

$$
\log \left(M_{\mathrm{o}}\right)=(17.60 \pm 0.37)+(1.12 \pm 0.10) * M_{\mathrm{L}}
$$

where $M_{\mathrm{L}}$ is the local magnitude obtained by converting duration magnitude $M_{\mathrm{d}}$ in $M_{\mathrm{L}}$ using the Tuvè et al. [53] empirical relationship.

$$
M_{\mathrm{L}}=1.164( \pm 0.011) * M_{\mathrm{d}}-0.337( \pm 0.020) .
$$

\section{Discussion and Conclusions}

In the last 40 years, three destructive seismic events with $I_{0}$ $=$ VIII have struck the eastern flank of Mt. Etna, namely, in 1984 (October 25), 2002 (October 29), and 2018 (December 26), as a result of the reactivation of the FF and SVF structures belonging to TFS.

Several authors have studied the 2002 and 2018 episodes in order to define the causes of the fault activation. In particular, Walter et al. [16] and Pulvirenti et al. [54] highlighted that Coulomb stress changes on the SVN, as induced by dike-forming intrusions only, were not sufficient to trigger the earthquake on October 29, 2002. Pulvirenti et al. [54] assessed that the necessary stress change value to trigger this earthquake is instead reached also considering the October 27 (01:28 GMT) Pernicana earthquake $\left(M_{\mathrm{d}}=3.5\right)$ and Coulomb stress changes (CSC). De Novellis et al. [24] and Mattia et al. [51] revealed that the 2018 intrusion prompted, with a positive loading, the seismic activation of FF.

We calculated the CSC $[55,56]$ induced by the intrusive episodes in order to analyse their relationships with flank sliding acceleration in causing a positive stress change to trigger the TFS. First, we have considered the sliding plane model of Palano et al. [57] and the intrusive sources modelled by Bonaccorso et al. [37] and Aloisi et al. [43, 47, 50] related to the 1991, 2002, 2008, and 2018 episodes. The sliding plane is ESE $11.6^{\circ}$ dipping with a top at $1.4 \mathrm{~km}$ b.s.l. and bottom at $3.9 \mathrm{~km}$ b.s.l. [57]. For calculations, we adopted a coefficient of friction of 0.4 (e.g., [58]), and we evidenced how intrusions encourage the flank movement showing the highest values in 2002 and decreasing in 2018, 2008, and 1991 (Figure 6).

We then considered, as the source, a sliding $(15 \mathrm{~cm})$ along the activated sector of the plane in Figure 6, verifying if the flank movement causes a positive stress change that may prompted both SVN and FF activations (Figure 7). We have taken into account geometric and kinematic parameters of the faults proposed by Azzaro et al. [9] considering a top at $0.5 \mathrm{~km}$ a.s.l. and a bottom at $1.0 \mathrm{~km}$ b.s.l. for FF and a top at $0.25 \mathrm{~km}$ a.s.l. and a bottom at 5.25 b.s.l. for SVN. The stress changes suggest that a right-lateral slip of the faults is encouraged (Figure 7).

In conclusion, these considerations show how the 2002 and 2018 activations of the Timpe Fault System may be considered the combined result of vigorous eruptive intrusions, sudden flank sliding acceleration, and related PFS activation.

In October 1984, no eruption occurred, but the seismicity beginning on the 16th showed some common features with intrusive seismic swarms:

(1) Location of the 1984 first phase (from the 16th at $14: 00$ to the 18 th at 12:00) is on the high eastern flank of Mt. Etna, similar to what was observed for other intrusive episodes such as the 1991, 2008, and 2018a events (Figure 8) involving similar volumes at depths between $1.5 \mathrm{~km}$ a.s.l. and $2.0 \mathrm{~km}$ b.s.l.

(2) Seismic parameters, such as activity rate (19 events/ hour) and cumulative seismic moment $\left(1.55 * 10^{16}\right.$ $\mathrm{Nm}$ ), are typical of the range of intrusive swarms at Mt. Etna (Table 2) 

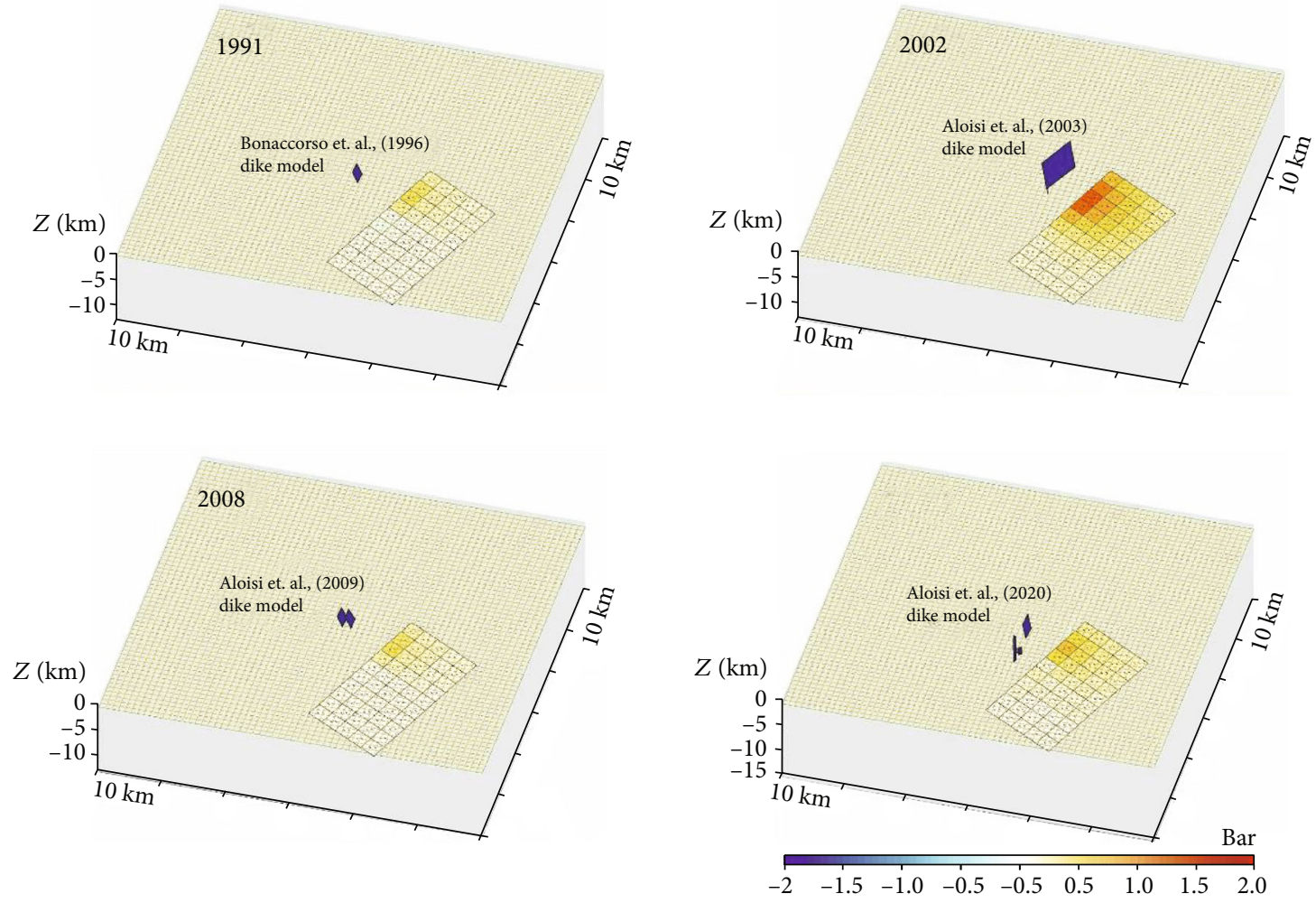

FIGURE 6: Coulomb stress changes on the sliding plane ([57], see Figure 9 for location) resulting from the 1991, 2002, 2008, and 2018 dike intrusion models. The intrusions and particularly the 2002 and 2007 triggered the flank movement of the northern sector of the plane.

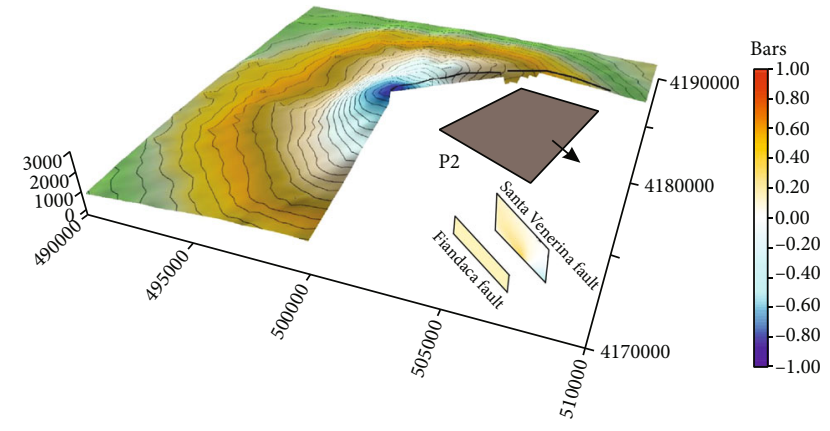

FIgURE 7: Coulomb stress changes on the FF and SVN faults resulting from activation of the north sector of the sliding plane (P2 in Figure 9).

These considerations suggest that the 1984 seismic swarm may be the result of an aborted intrusive magma episode that caused the acceleration of the eastern flank and the destructive earthquakes on TFS (Figure 9). Intrusions without eruption at Mt. Etna have been recognized in 1989 [59], in January 1998 [60], and during the 2018 eruption (2018b in Figure 4).

If so, it is interesting to note that the 1984, 2002, and 2018 seismic swarms show common features, such as the following:

(1) A duration greater than 15-20 hours (Table 2)

(2) A cumulative seismic moment (Figure 10) more than $10^{16} \mathrm{Nm}$
(3) A sudden activation of the PFS after a few hours, unlike the 1991, 2001, and 2008 events [10,11]

It should be emphasized that the 2001 episode, although it shows the highest duration and cumulative seismic moment, did not cause significant variations on PFS and on the eastern flank sliding.

Indeed, Bonaccorso et al. [61], by using numerical modelling, already assessed that eccentric intrusions in the south flank, as occurred during the 2001 eruption, do not cause a variation in stress able to promote earthquakes along the PFS. Modelling of GPS measurements instead reveals that the 2001 intrusion has activated a southward motion of the upper southern part of the volcano [39].

Therefore, in the last 40 years, we can pinpoint three cases in which strong intrusive seismic swarms are followed by rapid accelerations of the eastern flank (with PFS activation) and occurrence of destructive seismic events on the SVN and FF faults.

The time spans between the start of the intrusive swarm and the strong earthquakes are 1.8 days in 2018, 2.5 days in 2002, and 3.1 for the event on October 19, 1984, while the more destructive (October 25) earthquake occurred after 8.6 days.

Understanding the space-time evolution of eventual strong seismic swarms on the upper eastern and northeastern sectors of Etna is particularly important. If an intrusive seismic swarm occurs (with ground deformations) that extends over time ( $>10-15$ hours) accumulating a significant seismic moment $\left(>10^{16} \mathrm{~N} / \mathrm{m}\right)$ and activating the PFS, all 

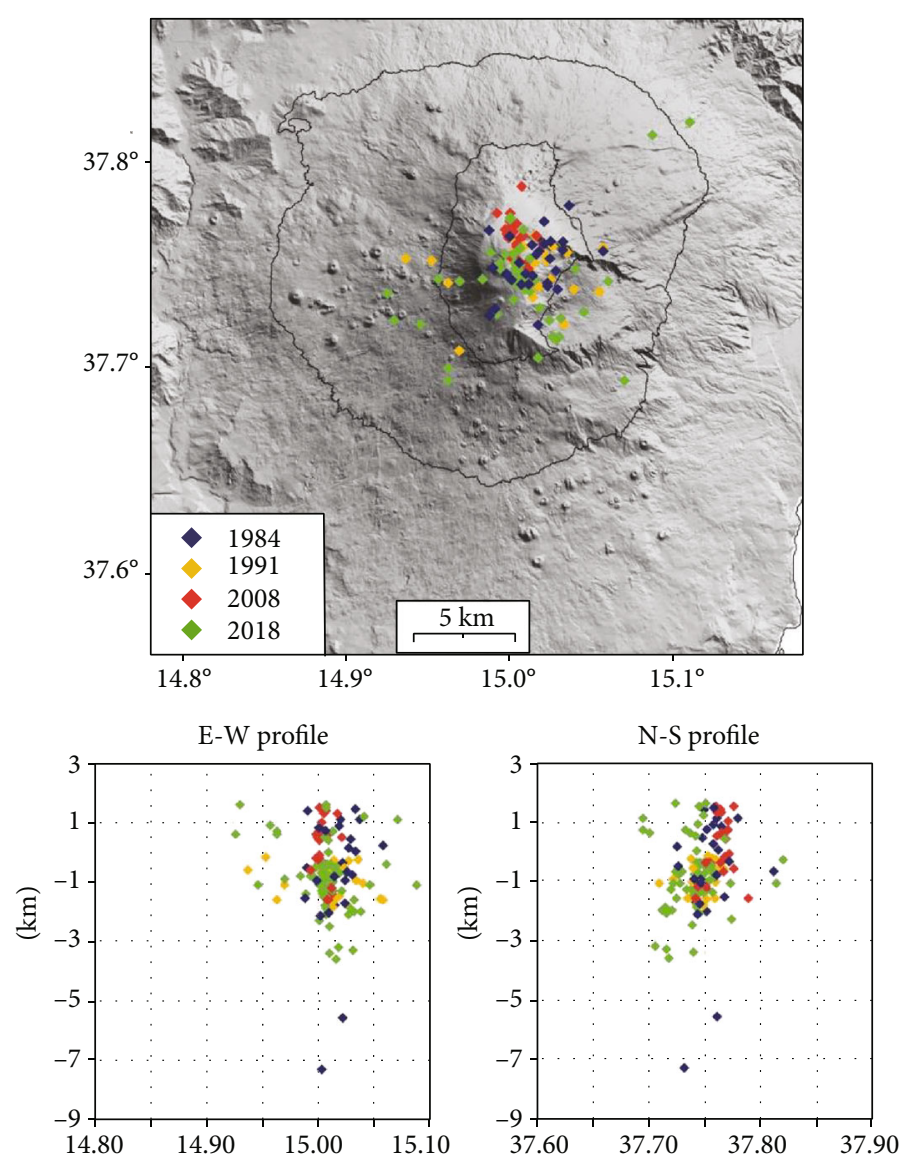

Figure 8: Map and cross sections of the located seismicity recorded during the 1984, 1991, 2008, and 2018a intrusive phases.

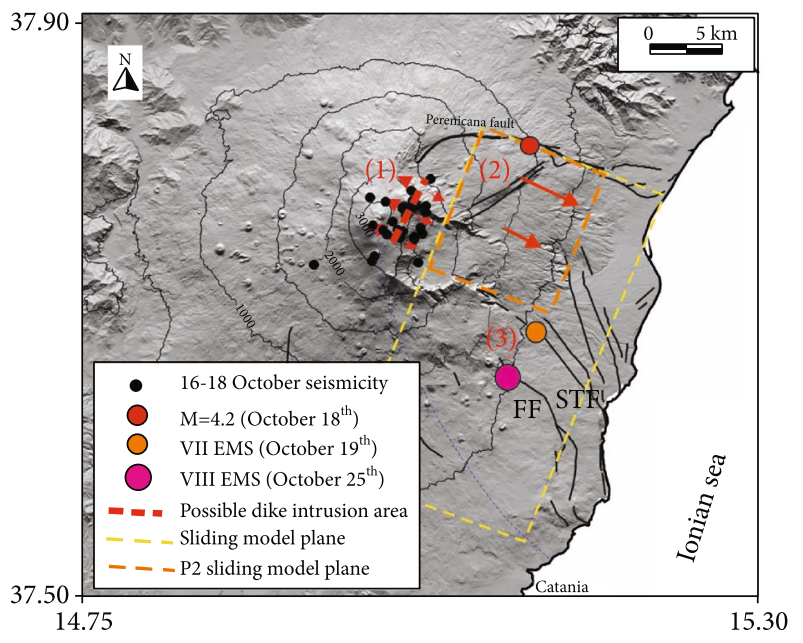

Figure 9: Sequence of the events that occurred in October 1984: (1) the seismic swarm is the result of an aborted magmatic intrusion that caused (2) the acceleration of the eastern flank (with PFS activation) and (3) the destructive earthquakes on TFS.

these elements can be a precursor-a few days ahead-of a fracturing event with strong seismic releases on the TFS.

The results of this work represent a starting point since it considers only three examples that deserve further validation and studies that could in turn lead to realizing an important alert system for those living close to the TFS in the future.

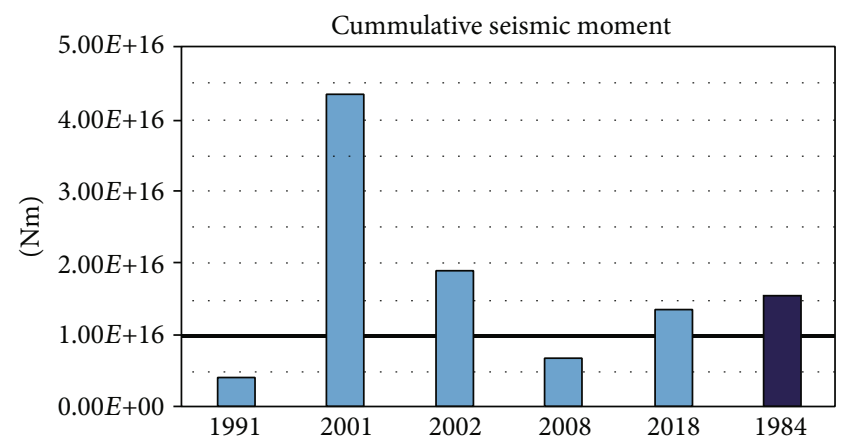

FIGURE 10: Cumulative seismic moment obtained for the intrusive seismic swarms.

\section{Abbreviations}

TFS: Timpe Fault System

FF: Fiandaca fault

STF: Santa Tecla fault

SVF: Santa Venerina fault

MOF: Moscarello fault

SLF: San Leonardello fault

ME: Malta Escarpment fault system

MF: Messina-Fiumefreddo line

EMS: European macroseismic scale

$M_{o}: \quad$ Seismic moment (dyne-cm)

$M_{L}: \quad$ Local magnitude 
$M_{d}$ : Duration magnitude

ATL: Aeolian-Tindari-Letojanni

CSC: Coulomb stress changes.

\section{Data Availability}

The data used to support the findings of this study are included within the supplementary information file.

\section{Disclosure}

A preliminary version of this manuscript has been presented as a preprint at the following link: https://www .researchsquare.com/article/rs-288277/v1A.

\section{Conflicts of Interest}

The authors have no conflicts of interest to declare that are relevant to the content of this article.

\section{Authors' Contributions}

SG contributed to the data curation, formal analysis, and investigation, wrote the original draft (lead), and reviewed and edited the paper. GD contributed to the data curation, formal analysis, and investigation.

\section{Acknowledgments}

We are particularly indebted to Marco Aloisi for his help during the review phase. We thank Stephen Conway for revising the English version of the manuscript.

\section{Supplementary Materials}

Location parameters of 636 seismic events recored between 16 and 31 October 1984. (Supplementary Materials)

\section{References}

[1] J. C. Bousquet and G. Lanzafame, "The tectonics and geodynamics of Mt. Etna: synthesis and interpretation of geological and geophysical data," in Etna Volcano Laboratory, Geophys. Monogr. Ser., A. Bonaccorso, S. Calvari, M. Coltelli, C. Negro, and S. Falsaperla, Eds., vol. 143, pp. 29-47, AGU, Washington, D.C., 2004.

[2] M. Neri, V. Acocella, B. Behncke, V. Maiolino, A. Ursino, and R. Velardita, "Contrasting triggering mechanisms of the 2001 and 2002-2003 eruptions of Mount Etna (Italy)," Journal of Volcanology and Geothermal Research, vol. 144, pp. 235-255, 2005.

[3] P. Allard, B. Behncke, S. D’Amico, M. Neri, and S. Gambino, "Mount Etna 1993-2005: anatomy of an evolving eruptive cycle," Earth Science Reviews, vol. 78, pp. 85-114, 2006.

[4] A. Bonforte, F. Guglielmino, M. Coltelli, A. Ferretti, and G. Puglisi, "Structural assessment of Mt. Etna volcano from permanent scatterers analysis," Geochemistry, Geophysics, Geosystems, vol. 12, p. Q02002, 2011.

[5] A. Borgia, L. Ferrari, and G. Pasquarè, "Importance of gravitational spreading in the tectonic and volcanic evolution of Mount Etna," Nature, vol. 357, no. 6375, pp. 231-235, 1992.
[6] V. Acocella, B. Behncke, M. Neri, and S. D’Amico, "Link between major flank slip and eruptions at Mt. Etna (Italy)," Journal of Geophysical Research, vol. 30, p. 2286, 2003.

[7] G. Solaro, V. Acocella, S. Pepe, J. Ruch, M. Neri, and E. Sansosti, "Anatomy of an unstable volcano from InSAR: multiple processes affecting flank instability at Mt. Etna, 1994-2008," Journal of Geophysical Research, vol. 115, p. B10405, 2010.

[8] A. Bonforte, A. Carnazzo, S. Gambino, F. Guglielmino, F. Obrizzo, and G. Puglisi, "A multidisciplinary study of an active fault crossing urban areas: the Trecastagni Fault at Mt. Etna (Italy)," Journal of Volcanology and Geothermal Research, vol. 251, pp. 41-49, 2013.

[9] R. Azzaro, A. Bonforte, S. Branca, and F. Guglielmino, "Geometry and kinematics of the fault systems controlling the unstable flank of Etna volcano (Sicily)," Journal of volcanology and geothermal research, vol. 251, pp. 5-15, 2013.

[10] S. Alparone, O. Cocina, S. Gambino et al., "Seismological features of the Pernicana-Provenzana fault system and implications for the dynamics of northeastern flank of the volcano," Journal of Volcanology and Geothermal Research, vol. 251, pp. 16-26, 2013.

[11] S. Alparone, A. Bonaccorso, A. Bonforte, and G. Currenti, "Long-term stress-strain analysis of volcano flank instability: the eastern sector of Etna from 1980 to 2012," Journal of Geophysical Research - Solid Earth, vol. 118, pp. 5098-5108, 2013.

[12] R. Azzaro, "Earthquake surface faulting at Mount Etna volcano (Sicily) and implications for active tectonics," Journal of Geodynamics, vol. 28, no. 2-3, pp. 193-213, 1999.

[13] R. Azzaro, M. S. Barbano, B. Antichi, and R. Rigano, "Macroseismic catalogue of Mt. Etna earthquakes from 1832 to 1998," Acta Vulcanologica, vol. 12, no. 1-2, pp. 3-36, 2000.

[14] C. Monaco, P. Tapponnier, L. Tortorici, and P. Y. Gillot, "Late quaternary slip-rates on the Acireale-Piedimonte fault system and tectonic origin of Mt. Etna.," Earth and Planetary Science Letters, vol. 147, pp. 125-139, 1997.

[15] R. Azzaro, "Seismicity and active tectonics in the Etna region: constraints for a seismotectonic model," in Mt. Etna: volcano laboratory, A. Bonaccorso, S. Calvari, M. Coltelli, C. Negro, and S. Falsaperla, Eds., vol. 143, pp. 205-220, American Geophysical Union, Geophysical monograph, 2004.

[16] T. R. Walter, V. Acocella, M. Neri, and F. Amelung, "Feedback processes between magmatic events and flank movement at Mount Etna (Italy) during the 2002-2003 eruption," Journal of Geophysical Research, vol. 110, no. B10, p. B10205, 2005.

[17] G. Grünthal, "European macroseismic scale 1998 (EMS-98). European seismological commission, subcommission on engineering seismology, working group macroseismic scales," Conseil de l'Europe, Cahiers du Centre Européen de Géodynamique et de Séismologie, vol. 15, p. 99, 1998.

[18] R. Azzaro, S. D'Amico, A. Mostaccio, L. Scarfi, and Y. Tuvè, "Terremoti con effetti macrosismici in Sicilia OrientaleCalabria Meridionale nel periodo Gennaio 2002 - Dicembre 2005," Quaderni di Geofisica, vol. 41, pp. 1-60, 2006.

[19] R. Civico, S. Pucci, R. Nappi et al., "Surface ruptures following the 26 December 2018, Mw 4.9, Mt. Etna earthquake, Sicily (Italy)," Journal of Maps, vol. 15, no. 2, pp. 831-837, 2019.

[20] C. Monaco, S. Catalano, O. Cocina et al., "Tectonic control on the eruptive dynamics at Mt. Etna volcano (eastern Sicily) during the 2001 and 2002-2003 eruptions," Journal of Volcanology and Geothermal Research, vol. 144, pp. 221-233, 2005. 
[21] A. Bonaccorso, A. Bonforte, F. Guglielmino, M. Palano, and G. Puglisi, "Composite ground deformation pattern forerunning the 2004-2005 Mount Etna eruption," Journal of Geophysical Research, vol. 111, p. B12207, 2006.

[22] A. Bonforte, A. Bonaccorso, F. Guglielmino, M. Palano, and G. Puglisi, "Feeding system and magma storage beneath Mt. Etna as revealed by recent inflation/deflation cycles," Journal of Geophysical Research, vol. 113, p. B05406, 2008.

[23] S. Calvari, G. Bilotta, A. Bonaccorso et al., "The VEI 2 Christmas 2018 Etna eruption: a small but intense eruptive event or the starting phase of a larger one?," Remote Sensing, vol. 12, p. $905,2020$.

[24] V. De Novellis, S. Atzori, C. De Luca et al., "DInSAR analysis and analytical modeling of Mount Etna displacements: the December 2018 volcano-tectonic crisis," Geophysical Research Letters, vol. 46, pp. 5817-5827, 2019.

[25] H. Langer, G. Tusa, L. Scarfi, and R. Azzaro, "Ground-motion scenarios on Mt. Etna inferred from empirical relations and synthetic simulations," Bulletin of Earthquake Engineering, vol. 14, pp. 1917-1943, 2016.

[26] F. Villani, S. Pucci, R. Azzaro et al., "Surface ruptures database related to the 26 December $2018, \mathrm{M}_{\mathrm{W}}$ 4.9 Mt. Etna earthquake, southern Italy," Scientific Data, vol. 7, no. 1, p. 42, 2020.

[27] S. Gresta, J. P. Glot, G. Patanè, G. Poupinet, and S. Menza, "The October seismic crisis at Mount Etna. Part I: space-time evolution of events," Annales de Geophysique, vol. 5B, no. 6, pp. 671-680, 1987.

[28] F. Cannavò, G. Gambino, B. Puglisi, and R. Velardita, "Modeling ground deformation associated with the destructive earthquakes occurring on Mt. Etna's southeastern flank in 1984," Natural Hazards and Earth System Sciences, vol. 16, pp. 2443-2453, 2016.

[29] S. Alparone and S. Gambino, "High precision locations of multiplets on south-eastern flank of Mt. Etna (Italy): reconstruction of fault plane geometry," Physics Earth and Planetary Interiors, vol. 135, pp. 281-289, 2003.

[30] S. Gambino, G. Distefano, V. Maiolino, and S. Gresta, "Seismic vs. geodetic moments at Mt. Etna volcano: a tool for a rapid understanding of eruptive behaviour?," Journal of Volcanology and Geothermal Research, vol. 367, pp. 1-6, 2018.

[31] S. Gresta and D. Patanè, "Review of seismological studies at Mount Etna," Pure and Applied Geophysics, vol. 125, pp. 951-970, 1987.

[32] J. C. Lahr, Hypoellipse Version 2.0*: A Computer Program for Determining Local Earthquake Hypocentral Parameters, Magnitude, and First Motion Pattern. United States Department of the Survey Menlo Park, Open File Report, California, 1989.

[33] A. Hirn, A. Nercessian, M. Sapin, F. Ferrucci, and G. Wittlinger, "Seismic heterogeneity of Mt. Etna: structure and activity," Geophysical Journal International, vol. 105, pp. 139-153, 1991.

[34] A. Ferro, S. Gambino, S. Panepinto, G. Falzone, G. Laudani, and B. Ducarme, "High precision tilt observation at Mt. Etna volcano, Italy," Acta Geophysica, vol. 59, no. 3, pp. 618-632, 2011.

[35] S. Gambino, G. Falzone, A. Ferro, and G. Laudani, "Volcanic processes detected by tiltmeters: a review of experience on Sicilian volcanoes," Journal of Volcanology and Geothermal Research, vol. 271, 2014.

[36] M. Palano, M. Rossi, F. Cannavò et al., "Etn@ref: a geodetic reference frame for Mt. Etna GPS networks," Annals of Geophysics, vol. 53, p. 4, 2010.
[37] A. Bonaccorso, F. Ferrucci, D. Patanè, and L. Villari, "Fast deformation processes and eruptive activity at Mt. Etna (Italy)," Journal of Geophysical Research, vol. 101, pp. 1746717480, 1996.

[38] D. E. Patané, F. Privitera, S. Ferrucci, and S. Gresta, "Seismic activity leading to the 1991-1993 eruption of Mt. Etna and its implications," Acta Vulcanologica, vol. 4, pp. 47-55, 1994.

[39] A. Bonforte, S. Gambino, and M. Neri, "Intrusion of eccentric dikes: the case of the 2001 eruption and its role in the dynamics of Mt. Etna volcano," Tectonophysics, vol. 471, no. 1-2, pp. 7886, 2009.

[40] B. Behncke and M. Neri, "The July-August 2001 eruption of Mt. Etna (Sicily)," Bulletin of Volcanology, vol. 65, pp. 461476, 2003.

[41] S. Gambino, "Continuous dynamic response along a preexisting structural discontinuity induced by the 2001 eruption at Mt Etna," Earth, Planets and Space, vol. 56, pp. 447-456, 2004.

[42] D. Patanè, E. Privitera, S. Gresta et al., "Seismological constraints for the dike emplacement of July-August 2001 lateral eruption at Mt. Etna volcano, Italy," Annals of geophysics, vol. 46, pp. 599-608, 2003.

[43] M. Aloisi, A. Bonaccorso, S. Gambino, M. Mattia, and G. Puglisi, "Etna 2002 eruption imaged from continuous tilt and GPS data," Geophysical Research Letters, vol. 30, no. 23, p. 2214, 2003.

[44] M. Aloisi, A. Bonaccorso, and S. Gambino, "Imaging compositive dike propagation (Etna, 2002 case)," Journal of Geophysical Research, vol. 111, p. B06404, 2006.

[45] S. Alparone, V. Maiolino, A. Mostaccio et al., "Instrumental seismic catalogue of Mt Etna earthquakes (Sicily, Italy): ten years (2000-2010) of instrumental recordings," Annals of Geophysics, vol. 58, no. 4, p. S0435, 2015.

[46] S. Alparone, G. Barberi, O. Cocina, E. Giampiccolo, C. Musumeci, and D. Patanè, "Intrusive mechanism of the 2008-2009 Mt. Etna eruption: Constraints by tomographic images and stress tensor analysis," Journal of volcanology and geothermal research, vol. 229, pp. 50-63, 2012.

[47] M. Aloisi, A. Bonaccorso, F. Cannavò et al., "A new dyke intrusion style for the Mount Etna May 2008 eruption modelled through continuous tilt and GPS data," Terra Nova, vol. 21, pp. 316-321, 2009.

[48] D. Patanè, "Quadro di sintesi e aggiornamento al 19 Maggio 2008 sullo stato di attività sismica dell'Etna, INGV internal report WKRSM20080519," 2008, http://www.ct.ingv.it/ Etna2007/main.htm.

[49] S. Alparone, G. Barberi, E. Giampiccolo et al., "Seismological constraints on the $2018 \mathrm{Mt}$. Etna (Italy) flank eruption and implications for the flank dynamics of the volcano," Terra Nova, vol. 11, pp. 1271-1282, 2020.

[50] M. Aloisi, A. Bonaccorso, F. Cannavò, G. Currenti, and S. Gambino, "The Dec 24, 2018 eruptive intrusion at Etna volcano as revealed by multi-disciplinary continuous deformation networks (CGPS, borehole strainmeters and tiltmeters)," Journal of Geophysical Research, vol. 125, no. 8, 2020.

[51] M. Mattia, V. Bruno, E. Montgomery-Brown, D. Patanè, G. Barberi, and M. Coltelli, "Combined seismic and geodetic analysis before, during, and after the 2018 Mount Etna eruption," Geochemistry, Geophysics, Geosystems, vol. 21, 2020.

[52] A. Bonaccorso and E. Giampiccolo, "Balance between deformation and seismic energy release: the Dec 2018 'double- 
dike' intrusion at Mt. Etna," Frontiers in Earth Science, vol. 8, 2020.

[53] T. Tuvè, S. D'Amico, and E. Giampiccolo, "A new Md-ML relationship for Mt. Etna earthquakes (Italy)," Annales de Geophysique, vol. 58, p. 6, 2015.

[54] F. Pulvirenti, M. Aloisi, and S. Jin, "Time-dependent Coulomb stress changes induced by the 2002-2003 Etna magmatic intrusions and implications on following seismic activities," Journal of Volcanology and Geothermal Research, vol. 344, pp. 185-196, 2017.

[55] J. Lin and R. S. Stein, "Stress triggering in thrust and subduction earthquakes, and stress interaction between the southern San Andreas and nearby thrust and strike-slip faults," Journal of Geophysical Research, vol. 109, p. B02303, 2004.

[56] S. Toda, R. S. Stein, K. Richards-Dinger, and S. Bozkurt, "Forecasting the evolution of seismicity in southern California: animations built on earthquake stress transfer," Journal of Geophysical Research, vol. 110, p. B05S16, 2005.

[57] M. Palano, G. Puglisi, and S. Gresta, "Ground deformation at Mt. Etna: a joint interpretation of GPS and InSAR data from 1993 to 2000," Bollettino di Geofisica Teorica ed Applicata, vol. 48, no. 2, pp. 81-98, 2007.

[58] A. Bonanno, M. Palano, E. Privitera, S. Gresta, and G. Puglisi, "Magma intrusion mechanisms and redistribution of seismogenic stress at Mt. Etna volcano (1997-1998)," Terra Nova, vol. 23, pp. 339-348, 2011.

[59] A. Bonaccorso and P. M. Davis, "Dislocation modelling of the 1989 dike intrusion into the flank of Mount Etna, Sicily," Journal of Geophysical Research: Solid Earth, vol. 98, pp. 42614268, 1993.

[60] A. Bonaccorso and D. Patanè, "Shear response to an intrusive episode at Mt. Etna volcano (January 1998) inferred through seismic and tilt data," Tectonophysics, vol. 334, pp. 61-75, 2001.

[61] A. Bonaccorso, G. Currenti, and C. Del Negro, "Interaction of volcano-tectonic fault with magma storage, intrusion and flank instability: a thirty years study at Mt. Etna volcano," Journal of Volcanology and Geothermal Research, vol. 251, pp. 98111, 2013.

[62] R. Azzaro and S. D’Amico, Catalogo Macrosismico dei Terremoti Etnei (CMTE), Istituto Nazionale di Geofisica e Vulcanologia (INGV), 2019.

[63] Gruppo Analisi Dati Sismici, Catalogo dei terremoti della Sicilia Orientale - Calabria Meridionale (1999-2020), INGV, Catania, 2020, http://sismoweb.ct.ingv.it/maps/eq_maps/sicily/ catalogue.php. 